\title{
PENGARUH MODEL PEMBELAJARAN KOOPERATIF TIPE TGT (TEAMS GAMES TOURNAMENT) TERHADAP HASIL BELAJAR MATEMATIKA
}

\author{
Sri Damayanti*1), M. Tohimin Apriyanto*2) \\ Universitas Indraprasta PGRI Jakarta $^{* 1}$, Universitas Indraprasta PGRI Jakarta ${ }^{* 2)}$
}

\section{INFO ARTICLES}

\section{Article History:}

Received: 3-03-2017

Revised: 11-03-2017

Approved: 19-03-2017

Publish Online: 17-06-2017

\section{Key Words:}

Cooperative Learning type TGT (Teams Games Tournament),

Mathematics Achievement

(c) $\underset{\text { EY }}{ }$ ()

\begin{abstract}
The research is aimed to determine the Impacts of Cooperative Learning type TGT ( Teams Games Tournament) on Mathematics Achievement at SDI Alfalah 1 Petang. Technique analysis used t test after fulfill a series of normality and homogeneity test. Based on normality test the data is in normal distribution, and for homogeneity through fisher test the data is homogen. Based on the research, it can be concluded that the average of student's achievement through cooperative TGT learning is more than cooperative learning type NHT (Numbered Heads Together). So, Cooperative Learning type TGT has positive Impacts on student's mathematics achievement on the students grade V at SDI Alfalah 1 Petang.
\end{abstract}

\begin{abstract}
Abstrak: Penelitian ini bertujuan mengetahui pengaruh pembelajaran kooperatif tipe TGT (Teams Games Tournament) terhadap Hasil Belajar Matematika di SDI Al-Falah 1 Petang. Teknik analisis data dengan menggunakan uji $t$ yang sebelumnya dilakukan uji persyaratan analisis data yaitu uji normalitas dengan menggunakan Uji Liliefors didapat data berdistribusi normal dan uji homogenitas menggunakan uji Fisher didapat data homogen. Dari hasil penelitian dapat disimpulkan bahwa rata-rata hasil belajar matematika siswa yang telah diberi model pembelajaran kooperatiftipe TGT (Teams Games Tournament) lebih tinggi daripada rata-rata hasil belajar matematika siswa yang diberi model pembelajaran kooperatif tipe NHT (Numbered Heads Together). Dengan demikian, model pembelajaran kooperatif tipe TGT (Teams Games Tournament) berpengaruh positif terhadap hasil belajar matematika pada siswa kelas V di SDI Al-Falah 1 Petang.
\end{abstract}

Correspondence Address: Jln. Raya Tengah Kelurahan Gedong, Pasar Rebo, Jakarta Timur, 13760, Indonesia; e-mail:dha_mey32@yahoo.com

How to Cite (APA $6^{\text {th }}$ Style): Damayanti, S., Apriyanto, M.T. (2017). Pengaruh Model Pembelajaran Kooperatif Tipe TGT (Teams Games Tournament) terhadap Hasil Belajar Matematika. JKPM (Jurnal Kajian Pendidikan Matematika), 02 (02), 235-244. DOI: 10.1007/XXXXXX-XX-0000-00

Copyright: Damayanti, S., Apriyanto, M. T. (2017)

Competing Interests Disclosures: The authors declare that they have no significant competing financial, professional or personal interests that might have influenced the performance or presentation of the work described in this manuscript. 


\section{PENDAHULUAN}

Dalam pembukaan UUD 1945 tercantum tujuan Nasional Indonesia yang berbunyi: ”...melindungi segenap bangsa Indonesia dan seluruh tumpah darah Indonesia dan untuk memajukan kesejahteraan umum, mencerdaskan kehidupan bangsa, dan ikut melaksanakan ketertiban dunia yang berdasarkan kemerdekaan, perdamaian abadi dan keadilan sosial...". Salah satu cara untuk mencapai tujuan nasional adalah melalui penyelenggaraan pendidikan untuk membentuk manusia yang berkualitas dan mampu berkompetisi dalam perkembangan ilmu pengetahuan maupun teknologi, sehingga dapat menghadapi era globalisasi yang penuh tantangan.

Pendidikan formal biasanya terjadi di sekolah, melalui proses pembelajaran. Undang-undang Sistem Pendididikan Nasional Nomor 20 tahun 2003 menyatakan bahwa pembelajaran adalah "Proses interaksi siswa dengan pendidik dan sumber belajar pada suatu lingkungan belajar". Interaksi belajar mengajar yang baik adalah guru sebagai pengajar tidak mendominasi kegiatan, tetapi membantu menciptakan kondisi yang kondusif serta memberikan motivasi dan bimbingan agar siswa dapat mengembangkan potensi dan kreativitasnya melalui kegiatan belajar.

Oleh karena itu dalam proses pembelajaran, faktor keaktifan siswa sebagai subjek belajar sangat menentukan.Siswa yang aktif memiliki semangat yang tinggi dalam memecahkan suatu masalah yang dihadapinya, tidak harus ada pada siswa yang ber-IQ tinggi. Namun bagi siswa yang berkemampuan ratarata sedang atau kurang dapat dilatih untuk memiliki karakter yang mampu menyelesaikan masalah diantaranya seperti soal matematika.

Manfaat diberikannya matematika pada jenjang pendidikan adalah menyiapkan siswa agar sanggup menghadapi perubahan dunia yang selalu berkembang melalui latihan bertindak atas dasar pemikiran secara logis, rasional, kritis, cermat, jujur, efektif dan efesien. Menurut Suherman, dkk (2001:58) mengatakan bahwa "siswa memerlukan matematika untuk memenuhi kebutuhan praktis dan pemecahan masalah dalam kehidupan sehari-hari".

Pada kenyataannya, sebagian besar siswa takut untuk mengikuti pelajaran matematika, hal ini disebabkan oleh karenasiswamenganggap matematika itu merupakan suatu mata pelajaran yang sulit dipelajari, sulit dipahami, dan sulit dimengerti. Butuh waktu dan energi yang ekstra untuk dapat memahami materi pelajaran matematika. Hal ini disebabkan karena siswa mengalami kejenuhan menghadapi simbolsimbol atau angka-angka dalam pelajaran matematika. Selama ini umumnya siswa di tingkat sekolah dasar hanya bermodal hafalan rumus matematika untuk menyelesaikan soal. Secara keseluruhan, relatif sangat sulit ditemukan siswa yang memiliki pemahaman secara komprehensif atas materi pelajaran matematika.

Pelajaran matematika masih menjadi masalah serius, hal ini dapat dilihat dari hasil belajar siswa pada pelajaran matematika yang masih di bawah rata-rata mata pelajaran pokok seperti Bahasa Indonesia dan Ilmu Pengetahuan Alam dalam Ujian Akhir Nasional (UAN). Di bawah ini adalah Data Nilai UAN SDI AlFalah 1 Petang yang diambil secara berturut-turut selama 3 periode akhir.

Tabel 1.Data Nilai UAN SDI Al-Falah 1 Petang

\begin{tabular}{cccc}
\hline Tahun Ajaran & Bahasa Indonesia & $\begin{array}{c}\text { Mata Pelajaran } \\
\text { Ilmu Pengetahuan Alam }\end{array}$ & Matematika \\
\hline $2012 / 2013$ & 6,75 & 6,50 & 5,00 \\
$2013 / 2014$ & 7,25 & 7,00 & 4,50 \\
$2014 / 2015$ & 7,50 & 7,25 & 4,25 \\
\hline
\end{tabular}

Sumber Data: Tata Usaha SDI Al-Falah

Dari data di atas dapat disimpulkan bahwa nilai matematika siswa SDI Al-Falah 1 Petang terkecil dibandingkan dengan pelajaran pokok lainnya dan terlihat dari tahun ke tahun nilai matematika menurun. 
Hal ini disebabkan oleh beberapa masalah klasik salah satu diantaranya karena model pembelajaran matematika yang digunakan guru kurang beragam, membosankan dan jarang melibatkan siswa dalam menyelesaikan suatu masalah. Oleh karena itu, salah satu usaha yang dapat dilakukan guru adalah merencanakan dan menggunakan model pembelajaran yang dapat mengkondisikan siswa agar belajar secara aktif, inovatif dan kritis. Dalam upaya meningkatkan hasil belajar siswa, guru tidak harus terpaku dengan menggunakan satu model pembelajaran. Guru sebaiknya juga menggunakan model yang bervariasi agar jalan pembelajaran tidak membosankan tetapi menarik perhatian siswa. Seorang guru harus kompeten dalam memilih suatu model pembelajaran untuk menyampaikan materi pelajaran.

Salah satu alternatif belajar yang dapat digunakan oleh guru untuk mengatasi masalah tersebut adalah dengan menggunakan model pembelajaran kooperatif, model pembelajaran kooperatif sangat dikenal pada tahun 1990-an, menurut Oxford Dictionary (dalam Eveline 2010:114) mendefinisikan kooperatif (cooperation) sebagai "bersedia untuk membantu." Kooperatif juga berarti bekerja sama untuk mencapai tujuan secara efektif dan efesien. Dalam model pembelajaran ini menekankan aktivitas kolaboratif siswa dalam belajar yang berbentuk kelompok, mempelajari materi pelajaran, dan memecahkan masalah secara kolektif kooperatif. Menurut Eveline (2010:115) menyatakan bahwa "Model pembelajaran kooperatif menuntut adanya modifikasi tujuan pembelajaran dari sekedar penyampaian informasi menjadi konstruktif pengetahuan oleh individu melalui belajar kelompok".

Salah satu tipe model pembelajaran kooperatif adalah Teams Games Tournament (TGT) menurut Isjoni (2010:83) mengatakan bahwa“"Model pembelajaran kooperatif tipe TGT merupakan salah satu tipe pembelajaran kooperatif yang menempatkan siswa dalam kelompok-kelompok belajar yang beranggotakan 4-6 orang siswa yang memiliki kemampuan, jenis kelamin dan ras yang berbeda". Perbedaan signifikan yang menjadikan model pembelajaran kooperatif TGT menjadi sangat menarik adalah karena diakhiri dengan game atau tournament. Dengan menggunakan model pembelajaran kooperatif tipe TGT diharapkan siswa mampu bekerja sama dalam tim sehingga menciptakan suatu kodisi yang dapat memberikan sentuhan dan kebiasaan agar siswa terampil dalam bekerja sama ataupun berkompetisi melalui tournament akademik.

Sebagai pembanding yang setara peneliti menggunakan model pembelajaran kooperatif tipe Numbered Head Together (NHT) karena model pembelajaran ini tidak berbeda jauh dari model pembelajaran kooperatif Teams Games Tournament (TGT), perbedaan dari keduanya terdapat pada proses belajarnya. Dalam model pembelajaran kooperatif tipe Numbered Head Together (NHT) siswa terlebih dahulu mengerjakan soal yang diberikan guru dengan cara mendiskusikan soal secara bersama-sama lalu dibahas secara menunjuk siswa melalui nomor yang terdapat pada siswa tersebut, sedangkan dalam model pembelajaran kooperatif Teams Games Tournament (TGT) siswa sudah mempersiapkan diri untuk menjawab pertanyaan.

Dengan penerapan model pembelajaran kooperatif tipe TGT ini diharapkan guru mampu memberikan rangsangan untuk melatih keterampilan-keterampilan yang spesifik dan siswa tidak merasa bosan serta mendapatkan meningkatkan hasil belajar matematika siswa. Untuk itu peneliti ingin melakukan penelitian eksperimen mengenai penggunaan model pembelajaran kooperatif tipe Teams Games Tournament (TGT) dalam pembelajaran matematika. Berdasarkan uraian diatas, maka penelitimelaksanakan penelitian mengenai Pengaruh model pembelajaran kooperatif tipe TGT (Teams Games Tournament)terhadaphasil belajar matematika di SDI Al-Falah 1 Petang. 


\section{METODE}

Penelitian ini dilaksanakan di SDI Al-Falah 1 Petang yang berada di Kecamatan Kebayoran Lama, Jakarta Selatan.Penelitian ini berlangsung selama 5 bulan, mulai bulan Maret 2016 sampai Juni 2016. Pada penelitian ini, peneliti menggunakan jenis penelitian kuantitatif. Penelitian kuantitatif yaitu suatu proses menemukan pengetahuan yang menggunakan data berupa angka sebagai alat untuk menemukan keterangan mengenai apa yang ingin kita ketahui. Adapun metode yang digunakan adalah metode penelitian quasi eksperimen. Penelitian ini dilakukan dengan membagi kelompok yang diteliti menjadi dua kelompok, yaitu kelompok eksperimen yang diberi perlakuan dengan model pembelajaran kooperatif tipe TGT (Teams Games Tournament) dan kelompok kontrol yang diberi perlakuan dengan model pembelajaran kooperatif tipe NHT (Numbered Head Together).

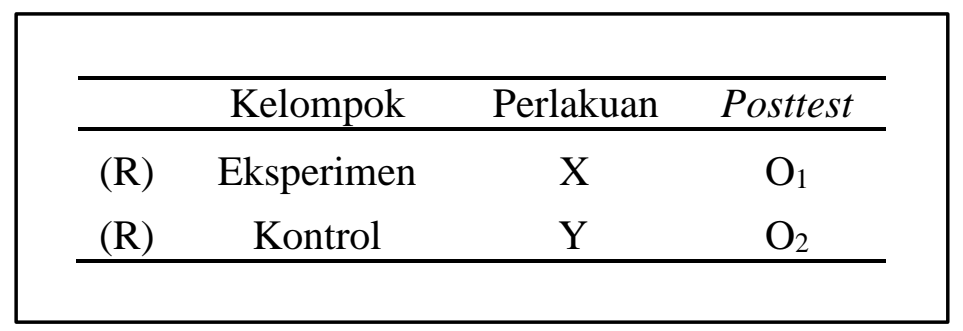

Gambar 1. Desain Penelitian

Keterangan:

$\mathrm{R} \quad$ : Pemilihan kelompok secararandom

$\mathrm{X} \quad$ : Perlakuan untuk kelaseksperimen

Y : Perlakuan untuk kelas kontrol

$\mathrm{O}_{1} \quad$ : Posttest kelompok eksperimen

$\mathrm{O}_{2} \quad$ : Posttest kelompok kontrol

Populasi target dalam penelitian ini adalah seluruh siswa kelas V SDI Al-Falah 1 Petang, karena menurut Arikunto (2006:130) menyatakan bahwa, "populasi adalah keseluruhan subjek penelitian". Sedangkan populasi terjangkau dalam penelitian ini adalah siswa kelas $\mathrm{V}$ semester genap tahun ajaran 2015/2016 yang berjumlah 60 siswa. Dalam pengambilan data, peneliti mengambil teknik sampling "simple random sampling". Riduwan (2010: 12) menyatakan bahwa, "Sampel acak (simple random sampling) adalah pengambilan sampel secara acak dari anggota populasi dengan menggunakan acak tanpa memperhatikan tingkatan dalam anggota tersebut". Jumlah sampelnya adalah 30 orang siswa dari kelas eksperimen dan kontrol.

\section{HASIL}

Penelitian ini memberikan perlakuan berbeda di kelompok eksperimen dan kontrol.Perlakuan untuk kelompok eksperimen berupa pembelajaran matematika dengan model pembelajaran kooperatif tipe TGT dan perlakuan untuk kelompok kontrol berupa pembelajaran kooperatif tipe NHT.Akan tetapi, ada hal yang dengan sengaja disamakan, yaitu jumlah tatap muka pembelajaran, yaitu masing-masing kelompok melaksanakan pembelajaran matematika sebanyak tujuh kali yang masing-masing dua jam pelajaran, dimana satu jam pelajaran berdurasi 35 menit. 
Dari hasil penelitian ini berupa skor hasil belajar matematika dari siswa yang diambil berupa posttest. Skor hasil belajar matematika berdasarkan 25 butir soal PG yang mungkin diperoleh adalah minimal 0 dan maksimal 100. Secara deskriptif, data hasil penelitian ini ditampilkan dalam Tabel 2.

Tabel 2. Ringkasan Hasil Perhitungan Statistik Deskriptif

\begin{tabular}{lllll}
\hline \multicolumn{2}{c}{ Kelompok } & Mean & Median & Modus \\
\hline Posttest & $\mathrm{E}$ & 66,43 & 66,94 & 65,1 \\
Posttest & $\mathrm{K}$ & 56,6 & 56,9 & 56,9
\end{tabular}

Sumber: Data primer yang diolah

Berdasarkan Tabel 2, dapat dilihat bahwa skor mean posttest kelompok eksperimen 66,43 dan kelompok kontrol 56,6, hal ini berarti terdapat perbedaan hasil belajar matematika siswa antara kelompok eksperimen dan kelompok kontrol. Akan tetapi, hal ini masih memerlukan pengujian lebih lanjut apakah terdapat perbedaan peningkatan hasil belajar matematika siswa pada taraf signifikansi 5\%. Namun, sebelum dilakukan pengujian hipotesis, terlebih dahulu harus dilakukan uji normalitas dan uji homogenitas.

Pengujian normalitas dilakukan untuk mengetahui distribusi data untuk setiap kelompok sampel yang diteliti berdistribusi normal atau tidak.Pengujian dilakukan dengan kriteria $\mathrm{L}_{\text {hitung }}<\mathrm{L}_{\text {tabel }}$ maka data dinyatakan berdistribusi normal, dan sebaliknya jika $L_{h i t u n g}>L_{\text {tabel }}$ maka data dinyatakan tidak berdistribusi normal.Berdasarkan tabel 3 di bawah ini, terlihat bahwa seluruh kelompok sampel yang diteliti memiliki $\mathrm{L}_{\text {hitung }}<\mathrm{L}_{\text {tabel}}$; sehingga dapat disimpulkan bahwa seluruh kelompok sampel dalam penelitian ini datanya berdistribusi normal.

Tabel 3. Ringkasan Hasil Uji Normalitas

\begin{tabular}{cccc}
\hline Variabel & $\mathrm{L}_{\text {hitung }}$ & $\mathrm{L}_{\text {tabel }}$ & Keterangan \\
\hline Posttest $\mathrm{E}$ & 011 & 0,16 & Data Berdistribusi Normal \\
Posttest $\mathrm{K}$ & 0,15 & 0,16 & Data Berdistribusi Normal \\
\hline
\end{tabular}

Sumber: Data primer yang diolah

Selanjutnya dilakukan uji persyaratan analisis data uji homogenitas. Pengujian homogenitas dimaksudkan untuk menguji apakah data dari masing-masing sampel mempunyai varians yang sama atau tidak. Perhitungan uji homogenitas dengan kriteria pengujian adalah jika $F_{\text {hitung }}<F_{\text {tabel }}$ maka data memiliki varians yang sama atau homogen, dan sebaliknya jika $F_{\text {Hitung }}>F_{\text {tabel }}$ maka data memiliki varians yang berbeda atau tidak homogen. Berdasarkan Tabel 4, terlihat bahwa variabel yang diteliti memiliki $\mathrm{F}_{\text {hitung }}<\mathrm{F}_{\text {tabel}}$; sehingga dapat disimpulkan bahwa data kedua sampel berasal dari populasi yang sama. Atau dengan kata lain data penelitian ini adalah homogen. 
Tabel 4. Ringkasan Hasil Uji Homogenitas

\begin{tabular}{cccc}
\hline Variabel & $\mathrm{F}_{\text {hitung }}$ & $\mathrm{F}_{\text {tabel }}$ & Keterangan \\
\hline Posttest & 1,83 & 1,9 & Homogen
\end{tabular}

Sumber: Data primer yang diolah

Pada analisis statistik secara inferensial, semua uji persyaratan analisis data terpenuhi, selanjutnya dilakukan perhitungan pengujian hipotesis.Pada penelitian ini, dilakukan pengujian hipotesis yaitu dengan uji t yang prosesnya dilakukan menggunakan bantuan Microsoft Excel 2007. Adapun kriteria pengujiannya adalah jika $t_{\text {hitung }}<t_{\text {tabel }}$ maka tidak terdapat perbedaan rata-rata, dan sebaliknya jika $t_{\text {hitung }}>t_{\text {tabel }}$ maka terdapat perbedaan rata-rata.Pengujian hipotesis ini adalah pengujian perbedaan rata-rata posttest pada kelompok eksperimen dan posttest pada kelompok kontrol. Hal ini jelas akan mengetahui apakah kemampuan akhir siswa setelah mendapatkan perlakuan pembelajaran yang berbeda adalah sama atau berbeda.

Tabel 5. Ringkasan Uji Beda Rata-rata Posttest Eksperimen dan Kontrol

\begin{tabular}{ccc}
\hline Kelompok Data & Posttest Eksperimen & Posttest Kontrol \\
\hline Mean & 66,43 & 56,6 \\
St. Deviasi & 13,252 & 11,484 \\
Varians & 175,61 & 152,7 \\
Banyak Subjek & 30 & 30 \\
Simpangan Baku & & \\
Skor thitung & & 3,3 \\
Skor tabel & 2,0 \\
Keterangan & Terdapat perbedaan yang signifikan hasil belajar matematika antara \\
& Posttest Eksperimen dan Posttest Kontrol
\end{tabular}

Sumber: Data primer yang diolah

Berdasarkan Tabel 5, terlihat bahwa terdapat rata-rata antara posttest kelompok ekperimen dan posttest kelompok kontrol. Hal ini menunjukkan bahwa terdapat perbedaan hasil belajar matematika setelah masingmasing kelompok sampel mendapatkan perlakuan yang berbeda. Oleh karena nilai rerata posttest kelompok eksperimen lebih tinggi daripada kelompok kontrol, artinya hasil belajar matematika siswa yang belajar dengan model pembelajaran kooperatif tipe TGT (Teams Games Tournament)lebih tinggi daripada siswa yang belajar dengan pembelajaran kooperatif tipe NHT(Numbered Head Together).

\section{PEMBAHASAN}

Berdasarkan perhitungan melalui uji t didapat nilai $t_{\text {hitung }}=3,3$ dan $t_{\text {tabel }}=2,0$ pada taraf signifikansi $\alpha=0,05$ dengan derajat kebebasan $=58$. Karena nilai $t_{\text {hitung }}(3,3)>t_{\text {tabel }}(2,0)$ maka $\mathrm{H}_{0}$ ditolak dan $\mathrm{H}_{1}$ diterima. Hal tersebut menunjukan bahwa rata-rata hasil belajar siswa lebih tinggi dibandingkan 
menggunakan model pembelajaran kooperatif tipe Number Head Together. Dengan diterimanya $\mathrm{H}_{1}$ memperlihatkan bahwa penarapan model pembelajarn kooperatif tipe Teams Games Tournament memberikan pengaruh yang positif terhadap kegiatan belajar di kelas V B SDI Al-Falah 1 Petang.

Selain dari hasil uji hipotesis, dari hasil analisis deskriptif juga diperoleh hasil belajar matematika siswa yang belajar dengan model pembelajaran kooperatif tipe TGT memperoleh skor rata-rata 66,43; sedangkan pada kelompok siswa yang belajar dengan menggunakan model pembelajaran kooperatif tipe NHT skor rata-rata 56,6. Dari nilai rata-rata tersebut terlihat bahwa model pembelajaran kooperatif tipe TGT menjadikan nilai rata-rata lebih tinggi dibandingkan model pembelajaran kooperatif tipe NHT.

Penggunaan model pembelajaran kooperatif tipe TGT memiliki pengaruh dalam hasil belajar matematika siswa. Hal ini dikarenakan dalam proses pembelajarannya, model pembelajaran ini menekankan kepada kerjasama antar kelompok untuk bekerja atau berdiskusi memahami informasi dan latihan sebelum kompetisi dengan kelompok lainnya dalam turnamen, sehingga pada model pembelajaran kooperatif tipe NHT dibuat kelompok sebanyak 5 sampai 6 orang perkelompoknya. Hal ini sejalan dengan pendapat Isjoni (2010: 83) menyatakan bahwa, "Model pembelajaran kooperatif tipe TGT merupakan salah satu tipe pembelajaran kooperatif yang menempatkan siswa dalam kelompok-kelompok belajar yang beranggotakan 4-6 orang siswa yang memiliki kemampuan, jenis kelamin dan ras yang berbeda".

Menurut Saco (dalam Rusman, 2012: 224) menyatakan bahwa "dalam model pembelajaran Teams Games Tournament (TGT) siswa memainkan permainan dengan anggota-anggota tim lain untuk memperoleh skor bagi tim mereka masing-masing”. Permainan dapat disusun guru dalam bentuk kuis berupa pertanyaan-pertanyaan yang berkaitan dengan materi pelajaran. Pembelajaran kooperatif dengan model TGT ini memiliki kesamaan dengan model STAD dalam pembentukan kelompok dan penyampaian materi tetapi menggantikan kuis dengan turnamen atau lomba dimana siswa memainkan game atau permainan akademik dengan anggota tim atau kelompok lain untuk meyumbangkan poin bagi skor tim atau kelompoknya. Teman satu tim atau kelompok akan saling membantu dalam mempersiapkan diri untuk permainan dengan mempelajari lembar kegiatan dan menjelaskan masalah-masalah satu sama lain, tetapi sewaktu siswa sedang bermain dalam game atau permainan, teman yang lain tidak boleh membantu, dan guru harus memperhatikan siswa benar-benarbertanggung jawab pada diri sendiri.Dalam pembelajaran kooperatif tipe TGT ini siswa sebelumnya telah belajar secara individual, untuk selanjutnya belajar kembali dalam kelompok masing-masing. Dan kemudian mengadakan turnamen atau lomba atau lomba dengan anggota kelompok lainnya sesuai dengan tingkat kemampuannya. Menurut Slavin (2011: 166) mengatakan bahwa, ada 5 komponen utama dalam penerapan model pembelajaran TGT, yaitu:

\section{Penyajian Kelas (Class Presentations)}

Pada awal pembelajaran guru menyampaikan materi dalam penyajian kelas atau sering juga disebut dengan presentasi kelas (class presentations). Kegiatan ini biasanya dilakukan dengan pengajaran langsung atau dengan ceramah yang dipimpin oleh guru.

Pada saat penyajian kelas ini siswa harus benar-benar memperhatikan dan memahami materi yang disampaikan guru, karena akan membantu siswa bekerja lebih baik pada saat kerja kelompok dan pada saat game atau permainan karena skor game atau permainan akan menentukan skor kelompok.

\section{Kelompok (Teams)}

Kelompok biasanya terdiri dari 4 sampai 6 orang siswa yang anggotanya heterogen dilihat dari prestasi akademik, jenis kelamin dan ras atau etnik. Fungsi kelompok adalah untuk lebih mendalami materi bersama teman kelompoknya dan lebih khusus untuk mempersiapkan anggota kelompok agar 
bekerja dengan baik dan optimal pada saat game atau permainan. Setelah guru memberikan penyajian kelas, kelompok (tim atau kelompok belajar) bertugas untuk mempelajari lembar kerja. Dalam belajar kelompok ini kegiatan siswa adalah mendiskusikan masalah-masalah, membandingkan jawaban, memeriksa, dan memperbaiki kesalahan-kesalahan konsep temannya jika teman satu kelompok melakukan kesalahan.

3. Permainan (Games)

Game atau permainan terdiri dari pertanyaan-pertanyaan yang relevan dengan materi, dan dirancang untuk menguji pengetahuan yang didapat siswa dari penyajian kelas dan belajar kelompok. Kebanyakan game atau permainan terdiri dari pertanyaan-pertanyaan sederhana bernomor. Game atau permainan ini dimainkan pada meja turnamen atau lomba oleh 3 orang siswa yang mewakili tim atau kelompoknya masing-masing. Siswa memilih kartu bernomor dan mencoba menjawab pertanyaan yang sesuai dengan nomor itu. Siswa yang menjawab benar pertanyaan itu akan mendapat skor. Skor ini yang nantinya dikumpulkan siswa untuk turnamen atau lomba mingguan.

4. Turnamen atau Lomba (Tournament)

Turnamen atau lomba adalah struktur belajar, dimana game atau permainan terjadi. Biasanya turnamen atau lomba dilakukan pada akhir minggu atau pada setiap unit setelah guru melakukan presentasi kelas dan kelompok sudah mengerjakan lembar kerja siswa (LKS). Turnamen atau lomba pertama guru membagi siswa ke dalam beberapa meja turnamen atau lomba. Tiga siswa tertinggi prestasinya dikelompokkan pada meja I, tiga siswa selanjutnya pada meja II dan seterusnya.

5. Penghargaan Kelompok (Team Recognition)

Setelah turnamen atau lomba berakhir, guru kemudian mengumumkan kelompok yang menang, masing-masing tim atau kelompok akan mendapat sertifikat atau hadiah apabila rata-rata skor memenuhi kriteria yang telah ditentukan. Tim atau kelompok mendapat julukan "Super Team" jika rata-rata skor 50 atau lebih, "Great Team" apabila rata-rata mencapai 50-40 dan "Good Team" apabila rata-ratanya 40 kebawah. Hal ini dapat menyenangkan para siswa atas prestasi yang telah mereka buat.

Dalam setiap model pembelajaran ada kelebihan dan kelemahannya, seperti dalam model pembelajaran ini juga terdapat kelebihan dan kelemahannya. Kelebihan dari pembelajaran kooperatif tipe Teams Games Tournament (TGT) menurut Slavin (2011: 100) mengatakan bahwa, sebagai berikut:

> Para siswa di dalam kelas-kelas yang menggunakan TGT memperoleh teman yang secara signifikan lebih banyak dari kelompok rasial mereka dari pada siswa yang ada dalam kelas tradisional.

Meningkatkan perasaan/persepsi siswa bahwa hasil yang mereka peroleh tergantung dari kinerja dan bukannya pada keberuntungan.

TGT meningkatkan harga diri sosial pada siswa tetapi tidak untuk rasa harga diri akademik mereka.

TGT meningkatkan kekooperatifan terhadap yang lain (kerja sama verbal dan nonberbal, kompetisi yang lebih sedikit).

Keterlibatan siswa lebih tinggi dalam belajar bersama, tetapi menggunakan waktu yang lebih banyak.

TGT meningkatkan kehadiran siswa di sekolah pada remaja-remaja dengan gangguan emosional, lebih sedikit yang menerima skors atau perlakuan lain.

Kelemahan dari Pembelajaran kooperatif tipe Teams Game Tournament (TGT) menurut sebagai berikut: 
Lebih meningkatkan pencurahan waktu untuk tugas.

Mengedepankan penerimaanterhadap perbedaan individu.

Dengan waktu yang sedikit dapat menguasai materi secara mendalam.

$>$ Proses belajar mengajar berlangsung dengan keaktifan dari siswa.

Mendidik siswa untuk berlatih bersosialisasi dengan orang lain.

Motivasi belajar lebih tinggi.

Hasil belajar lebih baik.

Meningkatkan kebaikan budi, kepekaan dan toleransi.

Pembelajaran kooperatif tipe Teams Game Tournament (TGT) mengharapkan agar para siswa lebih merasa senang dan nyaman dalam proses belajar mengajar dikelas. Sehingga dengan kondisi tersebut, siswa tidak lagi menganggap bahwa pelajaran matematika adalah pelajaran yang "menakutkan", melainkan suatu pelajaran yang menyenangkan.Model pembelajaran kooperatif tipe TGT (Teams Game Tournament) dapat memberikan motivasi yang lebih tinggi. Dengan demikian, pembelajaran itu sendiri akan meningkat. Seperti yang dikatakan oleh Slavin (2011: 4) mengatakan bahwa: "Pembelajaran kooperatif merujuk pada berbagai macam metode pengajaran dimana para siswa bekerja dalam kelompok-kelompok kecil untuk saling membantu satu sama lainya dalam mempelajari materi pembelajaran". model pembelajaran kooperatif tipe TGT memberikan kesempatan pada siswa untuk mendapatkan materi pembelajaran yang menarik dan dapat berinteraksi secara lebih luas.pembelajaran yang menyenangkan dan memotivasi siswa untuk berlombalomba dalam menjawab soal-soal yang diberikan dengan suasana hati yang riang gembira serta terciptanya kompetisi tim yang didasarkan pada tanggung jawab masing-masing individu.

\section{SIMPULAN}

Dari hasil penelitian dapat disimpulkan bahwa rata-rata hasil belajar matematika siswa yang telah diberi model pembelajaran kooperatif tipe TGT (Teams Games Tournament) lebih tinggi daripada rata-rata hasil belajar matematika siswa yang diberi model pembelajaran kooperatif tipe NHT (Numbered Heads Together). Dengan demikian, model pembelajaran kooperatif tipe TGT (Teams Games Tournament) berpengaruh positif terhadap hasil belajar matematika pada siswa kelas V di SDI Al-Falah 1 Petang.

Hasil penelitian mengenai penggunaan model pembelajaran kooperatif tipe Teams Games Tournament terhadap hasil belajar siswa SDI Al-Falah 1 Petang Jakarta Barat ini memberikan rekomendasi, diantaranya kepala sekolah dapat mendorong para guru untuk dapat meningkatkan kompetensi dalam mengajar agar terjadi peningkatan kualitas dalam mengajar dan meningkatkan hasil belajar siswa. Kemudian, seorang guru dapat menciptakan suasana belajar yang menyenangkan, salah satunya adalah dengan menggunakan model pembelajaran kooperatif tipeTeam Games Tournament sehingga siswa tidak merasa bosan dan menghilangkan pandangan negatif siswa terhadap guru dan ketakutan siswa dalam pelajaran, khususnya matematika.

Siswa tidak takut untuk mengeluarkan pendapat dan tidak menganggap guru sebagai orang yang menakutkan.Serta tidak membedakan status sosial dalam kelas. Karena itu semua akan menghambat keberhasilan dalam belajar. Jika terjadi hubungan kerjasama yang baik antara guru, siswa dan teman sebaya, tentunya akan mudah mencapai keberhasilan dalam meningkatkan hasil belajar siswa.Orangtua lebih meningkatkan perhatian pada pendidikan anak, sehingga dapat mendorong peningkatan hasil belajar di sekolah.Untuk penelitian selanjutnya diharapkan untuk menggunakan model pembelajaran yang lebih 
kreatif lagi sehingga banyak siswa yang menyukai pembelajaran matematika dan banyak guru yang disukai siswa

\section{DAFTAR RUJUKAN}

Arikunto, S. (2006). Prosedur Penelitian Suatu Pendekatan Praktik. Jakarta: Rineka Cipta

Departemen Pendidikan Nasional. Undang-undang Republik Indonesia No. 20 Pasal 3 tahun 2003 tentang Sistem Pendidikan Nasional.

Eveline. (2010). Pendekatan, Metode, Strategi, dan Model-Model Pembelajaran. Bandung: Nusa Media. Isjoni. (2010). Pembelajaran Kooperatif. Jogjakarta: Pustaka Belajar.

Riduwan. (2005). Belajar Mudah Penelitian untuk Guru, Karyawan dan Peneliti Pemula. Bandung: Alfabeta.

Riduwan. (2011). Dasar-dasar Statistika. Bandung: Alfabeta.

Rusman. (2012). Model-model pembelajaran mengembangkan profesionalisme guru. Jakarta: Raja Grafindo Persada.

Slavin, R. E. (2011).Cooperative Learning. Bandung: Nusa Media.

Suherman, E. dkk. (2001). Strategi Pembelajaran Matematika Kontemporer. Bandung: JICA UPI.

Syahrul, M. (2005). Langkah-langkah dan kelebihan serta kekurangan dari model pembelajaran teams games tournament. http://www.wawasanpendidikan.com. Diakses pada 20 Maret 2016. 